\section{DC サーボモータを用いた異常検出可能な パワーアシスト制御系設計*}

原

\title{
Power-Assist Controller Design Permitting Abnormality Detection by Means of DC Servomotor
}

\author{
Susumu HARA*2 \\ *2 Division of Electronics and Information Engineering, Toyota Technological Institute, \\ 2-12-1 Hisakata, Tempaku-ku, Nagoya-shi, Aichi, 468-8511 Japan
}

\begin{abstract}
Power-assist system (PAS) technology and its applications to manufacturing systems have attracted special interest recently. In such a man-machine system as PAS, the abnormality detection of the controlled mechanical part of the system, e.g., the collision detection of mechanical part, is extremely important. Some conventional studies have already proposed the collision detection methods for robots or PASs. In this study, we assume that DC servomotors are utilized as actuators. Then, this study proposes a novel power-assist controller design method. This method includes a software-based abnormality detection based on the current dynamics of motor. The controller design utilizes a two-degree-of-freedom control system structure which consists of an on-line linear simulator taking account of the current dynamics, an impedance controller and an LQI servo controller. The abnormality detection is realized by detecting the difference between the simulator's current and the real current of motor. The effectiveness of the method is verified experimentally.
\end{abstract}

Key Words: Motion Control, Servo Mechanism, Robot, Positioning, Power-Assist System, ManMachine System, Abnormality Detection, Collision Detection, Impedance Control

\section{1. はじめに}

産業用ロボットは各種生産現場において広く普及し ているが，ロボットでは自動化が困難であり，人間（作 業者) が直接作業を行う工程もなお多い. 例えば自動車 組み立て工程では, 作業者自身が重い対象物を移動さ せて目的の取り付け位置に位置決めする作業が見られ

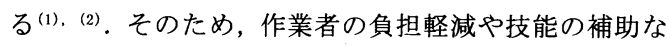
どを目的として，インピーダンス制御 ${ }^{(3)}$ の考え方を導 入したパワーアシスト機器の利用が考えられている. 山田らは熟練作業者がもともと習得している運動調整 機能 (スキル)の発揮を支援するスキルアシストの導入 を提案している(1)，(2)。組み立て工程を考えた他のパ ワーアシスト機器には林らの研究があり, 最適可変イ ンピーダンス制御の適用を図っている(4). また, 近藤ら も組み立て工程への応用を念頭に, 人間一機械共働系と 呼ばれる概念に基づいた, パワーアシストの利用方法を 説明している(5).さらに, 三好らはクレーンなど柔軟な 構造物に対するパワーアシストの手法を検討している (6). 著者も最近, 自動的な搬送過程とパワーアシストを

* 原稿受付 2005 年 5 月 19 日。

*1 正員, 豊田工業大学電子情報系(焉468-8511 名古屋市天白 区久方 2-12-1).

E-mail : haras@ toyota-ti.ac.jp
用いた人間主体の作業過程を同一のアクチュエータに よりなめらかに切り換えて実現するための各種制御手 法(7) (12) やパワーアシストシステムのためのロバスト性 向上に関する提案 ${ }^{(13)}$ などを行っている. 特に前者は, 制御対象の運動を停止することなく, 機械主体の制御 から人間主体の制御人，ないしはその逆になめらかに 切り換えることを可能としており, 作業効率化のみな らず, 作業者の快適性を向上させるなど効果は大きい. 著者の提案内容ではいずれも D C サーボモータをアク チュエータに使用している. 近年, ACサーボモータの 採用拡大により利用が減っているものの, 特種なドラ イバなしにパワーアンプで制御できるD Cサーボモー 夕は, 制御が容易なアクチュエータとして長い間使わ れてきた. なお, 著者の従来の提案では制御を実現する のに制御対象の加速度の計測を必要としていた ${ }^{(7) ~(13) . ~}$

一般に, パワーアシスト機器を利用することによる 最大の恩恵は, 実際よりもはるかに軽い物体であるか のように感じながら，作業者が制御対象を移動したり 位置決めできる点であろう. しかしながら，この長所が 何らかの異常状態を招きやすくなることも考えられる. 例えば, 制御対象の何らかの障害との衝突や異物の挟 み込み等の発生である。これらは機器の故障はもとよ り, 作業者の安全を脅かす事態になり兼ねない. よっ 
て, パワーアシスト機器のような人間一機械系では, こ のような異常状態を機器自身が検出し, それまでの制 御を停止し, その後何らかの対応が容易に取り得る対 処方法を備えていることが重要である.

加藤らは, 床面等への接触時の安定性を考慮したパ ワーアシスト機器のインピーダンス制御手法を提案し, 接触を検出中は開ループ型の力制御に切り換える手法 を提案している(14).もともと, 自律的なロボットの衝 突検出に関しては以前から研究されており, Lumelsky らのセンサを用いる方法 ${ }^{(15)}$, センサを用いないソフト ウェア的な検出手法としてはTakakura $ら^{(16)}$, 山田ら ${ }^{(17)}$ の外乱オブザーバを用いる方法や小菅らの適応制御を 用いる方法(18)などがある.

上記のような背景を踏まえ, 本研究でもソフトウェ ア的に異常状態を検出可能なパワーアシスト制御系の 設計法を提案する. 異常検出は前述の他の研究内容 ${ }^{(15)}$ 〜(18)を付加することでも可能であるが, 本研究では, 著 者がこれまでに提案した制御系と同様の構成のままで 異常検出可能な手法を提案する. 本研究においてもD Cサーボモータの使用を前提とする.ただし, 制御対象 の加速度の計測が不要な制御則を考える. その上で, モ一夕電流の動特性を導入して推定した電流と実際の 電流との差から異常状態を検出する手法を提案する.す なわち, 本手法では障害との衝突や異物の挟み込み等に よりモータに負担が生じ, 実際の電流が大きく変化する 種類の異常に対応できる. 本手法により, 従来著者が提 案した各種制御手法をソプトウェア上の小さな変更のみ で,より安全性を向上しながら実装することが可能とな る.よって, 著者の従来手法の実用性は大きく向上す る. $\mathrm{X}$-Yテーブルを改造した簡単なロボットシステム (9) (12) を選び, 実験により提案する手法の有用性を検討 している.

\section{2. 制御対象例とインピーダンス制御則}

$2 \cdot 1$ 制御対象例本研究では, 市販の $\mathrm{X}-\mathrm{Y}$ テー ブルを改造した図 1 のような簡単なロボットシステム を制御対象として採用する．実際のロボットシステム の写真を図 2 に示す. 本システムはェンコーダ付き D Cサーボモータとタイミングベルトから成る駆動系に より駆動されるテーブルと, テーブル上の台の頂上に 設置されたハンドルのついたカ覚センサ, 制御演算に 必要なD S P(Digital Signal Processor, TMS320C31)やパ ワーアンプなどから構成される.この構成を図 3 に示 す. 本研究では運動方向を 1 軸に限定して議論する. 実 験時にはモータのエンコーダからテーブル変位を検出 し，それを差分近似してテーブル速度を得る。作業者は 台上のハンドルを握って操作する. ハンドル直下にあ

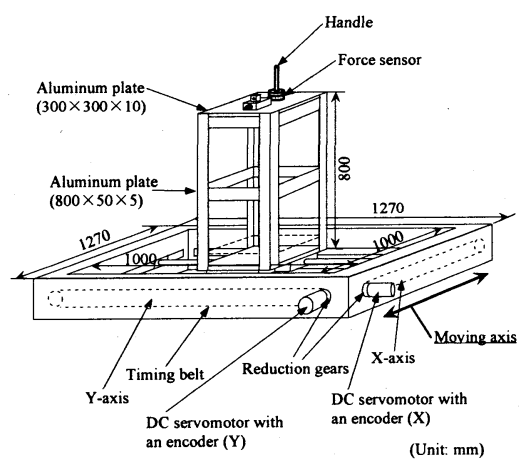

Fig. 1 Robotic system in this study

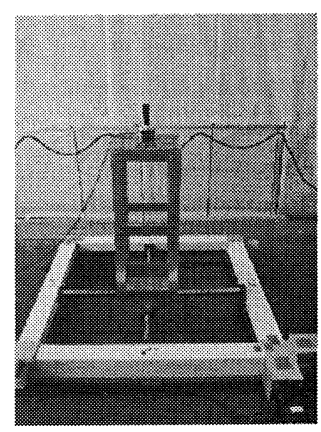

Fig. 2 Photo of the robotic system

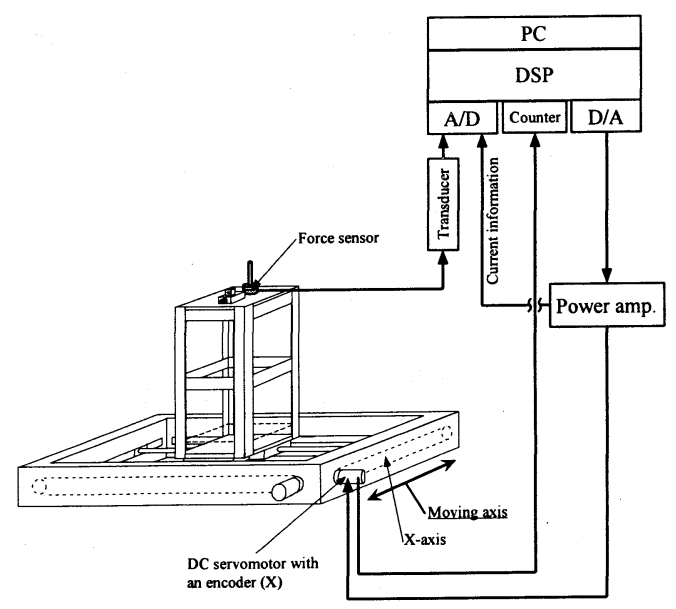

Fig. 3 Control system diagram of the robotic system

る力覚センサから作業者の操作力が検出される. D S P ではサンプリング周期 $1.0 \mathrm{~ms}$ で制御演算が行われ, 制御 入力がモータに対する電圧信号としてパワーアンプに送 られる.パワーアンプがモータを駆動することで制御が 実現される.

図 1 の制御対象は駆動系の固体摩擦などを無視する と, これまでの研究を参考にして図 4 のようにモデル 


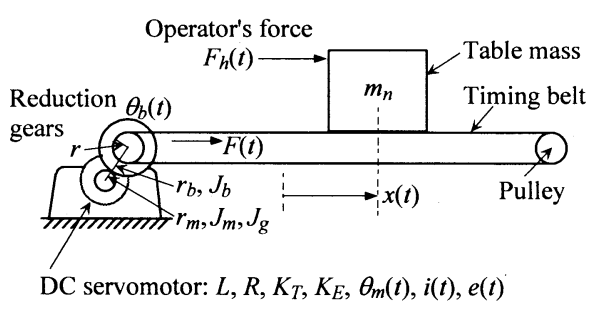

Fig. 4 Controlled object model

Table 1 Parameters of the robotic system

\begin{tabular}{c|l|c}
\hline$m_{n}$ & Equivalent mass of the table and stand & $28.0 \mathrm{~kg}$ \\
\hline$J_{b}$ & Moment of inertia (Base side gear and the pulley) & $3.57 \times 10^{-5} \mathrm{~kg} \cdot \mathrm{m}^{2}$ \\
\hline$J_{m}$ & Moment of inertia (Motor) & $8.33 \times 10^{-4} \mathrm{~kg} \cdot \mathrm{m}^{2}$ \\
\hline$J_{g}$ & Moment of inertia (Motor side gear) & $8.33 \times 10^{-4} \mathrm{~kg} \cdot \mathrm{m}^{2}$ \\
\hline$r$ & Radius of the pulley & $0.0159 \mathrm{~m}$ \\
\hline$\alpha$ & Gear ratio $\left(=r_{b} r_{m}\right.$ ) & 11.0 \\
\hline$L$ & Inductance of the motor & $2.0 \mathrm{mH}$ \\
\hline$R$ & Resistance of the motor & $1.0 \Omega$ \\
\hline$K_{T}$ & Torque constant of the motor & $0.215 \mathrm{~N} \cdot \mathrm{m} / \mathrm{A}$ \\
\hline$K_{E}$ & Back electromotive force constant of the motor & $0.215 \mathrm{~V} \cdot \mathrm{s} / \mathrm{rad}$ \\
\hline$f_{r}$ & Coulomb friction force of the driving system & $131.4 \mathrm{~N}$ \\
\hline \multicolumn{2}{|l}{} \\
\multicolumn{2}{|l}{}
\end{tabular}

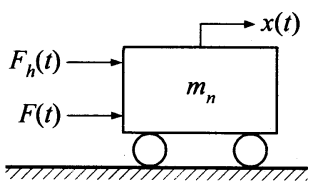

Fig. 5 Simple model

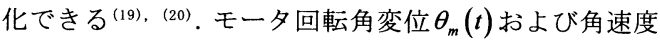
$\dot{\theta}_{m}(t)$, モー夕電流 $i(t)$ を状態量とし, モー夕電圧 $e(t)$ を制御入力と考える.また，作業者操作力を $F_{h}(t)$ とし た場合の制御対象の状態方程式は次のようになる.

$$
\begin{aligned}
& \dot{\boldsymbol{x}}(t)=\boldsymbol{A x}(t)+\boldsymbol{b u}(t)+\boldsymbol{h} F_{h}(t) \cdots \cdots(1) \\
& \boldsymbol{x}(t)=\left[\begin{array}{lll}
\theta_{m}(t) & \dot{\theta}_{m}(t) & i(t)
\end{array}\right]^{\mathrm{T}}, \quad u(t)=e(t) \\
& \boldsymbol{A}=\left[\begin{array}{ccc}
0 & 1 & 0 \\
0 & 0 & \frac{\alpha K_{T}}{r I_{l}} \\
0 & -\frac{K_{E}}{L} & -\frac{R}{L}
\end{array}\right], \quad \boldsymbol{b}=\left[\begin{array}{c}
0 \\
0 \\
\frac{1}{L}
\end{array}\right], \quad \boldsymbol{h}=\left[\begin{array}{c}
0 \\
\frac{1}{I_{l}} \\
0
\end{array}\right]
\end{aligned}
$$

ただし， $I_{l} \equiv \frac{r}{\alpha} m_{n}+\frac{\alpha}{r}\left(J_{m}+J_{g}\right)+\frac{1}{\alpha r} J_{b}$ である.図 4 およ び式 (1) 中の各パラメータは表 1 中に示す意味を持つ. パラメータの具体的な值については実際の装置を参考 にすると, 表 1 中のような値となる.

本研究の制御対象のように,インダクタンスの影響が 比較的小さいモータを使用する場合には, ほぼ次の関係 が成り立つことが知られている(21).

$$
i(t)=-\frac{K_{E}}{R} \dot{\theta}_{m}(t)+\frac{1}{R} e(t) \cdots \cdots . . .
$$

式 (2) を用いると, 状態量から電流を省くように式 (1) の状態方程式は次のように書き換えられる.

$$
\begin{aligned}
& \dot{\boldsymbol{x}}_{c}(t)=\boldsymbol{A}_{c} \boldsymbol{x}_{c}(t)+\boldsymbol{b}_{c} u(t)+\boldsymbol{h}_{c} F_{h}(t) \cdots \\
& \boldsymbol{x}_{c}(t)=\left[\begin{array}{ll}
\theta_{m}(t) & \dot{\theta}_{m}(t)
\end{array}\right]^{\mathrm{T}}, \quad u(t)=e(t) \\
& \boldsymbol{A}_{c}=\left[\begin{array}{cc}
0 & 1 \\
0 & -\frac{\alpha K_{T} K_{E}}{r I_{l} R}
\end{array}\right], \quad \boldsymbol{b}_{c}=\left[\begin{array}{c}
0 \\
\frac{\alpha K_{T}}{r I_{l} R}
\end{array}\right], \quad \boldsymbol{h}_{c}=\left[\begin{array}{l}
0 \\
\frac{1}{I_{l}}
\end{array}\right]
\end{aligned}
$$

著者の従来の提案 ${ }^{(7)} \sim(13)$ では, 図 5 のような単純な 2 重積分系のモデルに基づいて制御則を導いていた。こ のモデルの状態方程式は

$$
\begin{array}{ll}
\dot{\boldsymbol{x}}_{\text {dim }}(t)=\boldsymbol{A}_{\text {dim }} \boldsymbol{x}_{\text {dim }}(t)+\boldsymbol{b}_{\text {dim }} F(t)+\boldsymbol{h}_{\text {dim }} F_{h}(t) \cdots(4) \\
\boldsymbol{x}_{\text {dim }}(t)=\left[\begin{array}{ll}
x(t) \\
\dot{x}(t)
\end{array}\right], \quad \boldsymbol{A}_{\text {dim }}=\left[\begin{array}{ll}
0 & 1 \\
0 & 0
\end{array}\right] \\
\boldsymbol{b}_{\text {dim }}=\left[\begin{array}{ll}
0 & \frac{1}{m_{n}}
\end{array}\right]^{\mathrm{T}}, \quad \boldsymbol{h}_{\text {dim }}=\left[\begin{array}{ll}
0 & \frac{1}{m_{n}}
\end{array}\right]^{\mathrm{T}}
\end{array}
$$

であるから, 式(3)と（4）を比較し，モータに次のよう な電圧 $e(t)$ を与えることで式 (4)の動特性を実現した。

$$
\begin{aligned}
e(t)= & \frac{R}{K_{T}}\left(J_{m}+J_{g}+\frac{J_{b}}{\alpha^{2}}\right) \ddot{\theta}_{m}(t) \\
& +K_{E} \dot{\theta}_{m}(t)+\frac{r R}{\alpha K_{T}} F(t) \ldots . . .
\end{aligned}
$$

しかしながら，この場合には式 (5) 中のモータ回転角 速度 $\dot{\theta}_{m}(t)$ のみならずモータ回転角加速度 $\ddot{\theta}_{m}(t)$ を計測 し,フィードバックできるものとしていた.この仮定で は加速度センサの設置などが求められる。本研究では より容易に制御を実現するために加速度の計測を必要 としない定式化をしておく．具体的には，式(3)のモデ ルから直接制御則を導く、詳細は次節で述べる.

$2 \cdot 2$ インピーダンス制御則 インピーダンス制御 を用いる研究では, 作業者にとって式(6)のインピーダ ンス特性が得られるようにインピーダンス制御入力を 考えるものが多い(1), (7) (13).

$$
m_{d} \ddot{x}(t)+c_{d} \dot{x}(t)=F_{h}(t) \cdots \cdots \cdot \cdots \cdot
$$

ここで, $m_{d}$ と $c_{d}$ はそれぞれ作業者に対して呈示される インピーダンス特性上の質量 $[\mathrm{kg}]$ と粘性减衰係数 $[\mathrm{N} \cdot \mathrm{s} / \mathrm{m}]$ を意味する. $m_{d}, c_{d}$ をまとめてインピーダンス パラメータと呼ぶ. 式 (4)の制御対象に対して, 式 (6) の特性を得るために与えるべき $F(t)$ は次のようになる.

$$
F(t)=-\frac{m_{n}}{m_{d}} c_{d} \dot{x}(t)-\left(1-\frac{m_{n}}{m_{d}}\right) F_{h}(t) \ldots .
$$

このことは式(7)を式(4)に代入して式(6)の特性が得ら れることから容易に理解できる. 本研究では式 (6), (7)を用いずに, 式(3)の制御対象に対して下記のイン ピーダンス特性が得られることを目指す.

$$
I_{l d} \ddot{\theta}_{m}(t)+D_{d} \dot{\theta}_{m}(t)=F_{h}(t) \cdots \cdots \cdots(8)
$$

ただし, $I_{l d}=\frac{r}{\alpha} m_{d}+\frac{\alpha}{r}\left(J_{m}+J_{g}\right)+\frac{1}{\alpha r} J_{b}, D_{d}$ は定数であ る. 式(8)の特性を得るために与えるべき式(3)の $u(t)$ は次のようになる. 


$$
u(t)=\left(K_{E}-\frac{r R}{\alpha K_{T}} \frac{I_{l}}{I_{l d}} D_{d}\right) \dot{\theta}_{m}(t)-\frac{r R}{\alpha K_{T}}\left(1-\frac{I_{l}}{I_{l d}}\right) F_{h}(t)
$$

このことも式(7)同様, 式 (9) を式 (3) に代入して式 (8) の特性が得られることから理解できる. 式(5)は式(3) 左辺の角加速度と右辺第 1 項の逆起電力に関わる項を打 ち消すことで, 式 (4)の 2 重積分系モデルと同等になる ような制御入力電圧を求めており, その上で式 (7)のイ ンピーダンス制御入力を考えている. 一方, 式(9)は式 (3) と (8) の連立方程式から $\ddot{\theta}_{m}(t)$ を消去するように直接 インピーダンス制御入力電圧を求めている.

式 $(9)$ では, $\dot{\theta}_{m}(t)$ と $F_{h}(t)$ のフィードバックのみでイ ンピーダンス制御が実現され, $\ddot{\theta}_{m}(t)$ の計測は不要とな る. 式(8)は $\theta_{m}(t)=(\alpha / r) x(t)$ から,

$$
\frac{\alpha}{r} I_{l d} \ddot{x}(t)+\frac{\alpha}{r} D_{d} \dot{x}(t)=F_{h}(t) \cdots \cdots(10)
$$

のように書け, さらに, 次のように書き換えられる.

$$
\begin{aligned}
& m_{d}^{\prime} \ddot{x}(t)+c_{d} \dot{x}(t)=F_{h}(t) \ldots \ldots . . . . .(11) \\
& m_{d}^{\prime}=m_{d}+I_{J}, \quad I_{J}=\frac{1}{r^{2}}\left[\alpha^{2}\left(J_{m}+J_{g}\right)+J_{b}\right], \quad c_{d}=\frac{\alpha}{r} D_{d}
\end{aligned}
$$

すなわち, 式(6)ないしは図 5 のような 1 質点のモデル に例えれば, 式(11) はそのモデルに対し, $m_{d}^{\prime}, c_{d}$ のイン ピーダンス特性を実現する制御入力が式(9)に相当する ことを意味する. $I_{l d}$ や $D_{d}$ と比較して, オペレータが 希望する $m_{d}^{\prime}, c_{d}$ の值は従来の研究を参考にして決めや すい. そこで, インピーダンス制御の設計では, 設計者 が $m_{d}^{\prime}, c_{d}$ の值を選ぶ. $I_{J}$ や $\alpha / r$ が定数であることから $m_{d}$ や $D_{d}$ が決定できる. ゆえに式(9)から必要な制御 入力が求められる. 本研究ではこの手順で制御器設計 を行う。

\section{3. 異常検出可能なパワーアシスト制御系設計}

$3 \cdot 1$ 制御系の構造著者は文献 (13)において, 主 に駆動系に存在する不確かな固体摩擦の影響に着目し, その影響を抑制できる, パワーアシストシステムのロ バスト制御系設計法を提案した。 その制御系の構造を 図 6 に示す.この手法の基本的な概念は, 各種ロバスト 制御手法の適用において考えられてきた, 一部の 2 自 由度制御系の方法と類似している(20) (22). 文献 (13)の みならず, 著者はこれまで同様の構造を利用し, 複数の 制御手法を提案してきた ${ }^{(9)}$ (12). この構造では, 作業者 が対象に与えた操作力を, 固体摩擦のないノミナル系 の応答を計算するオンラインシミュレータに与え, こ の状態量と操作力からインピーダンス制御入力を求め る.インピーダンス制御入力はアクチュエータに与え られるのみならず, オンラインシミュレータにも フィードバックされる. そしてシミュレータが生成す る目標軌道からの実際の応答の偏差を抑圧するために

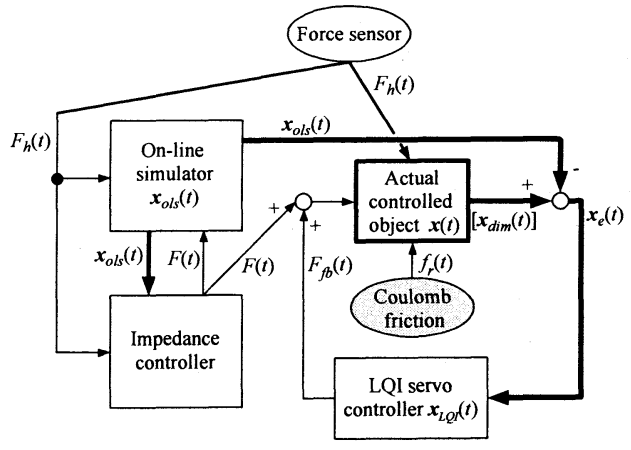

Fig. 6 Control system structure in the conventional method (In the study of this paper, $F(t), F_{f b}(t)$ and $x_{\text {dim }}(t)$ are replaced by $u(t), u_{f b}(t)$ and $x_{c}(t)$, respectively.)

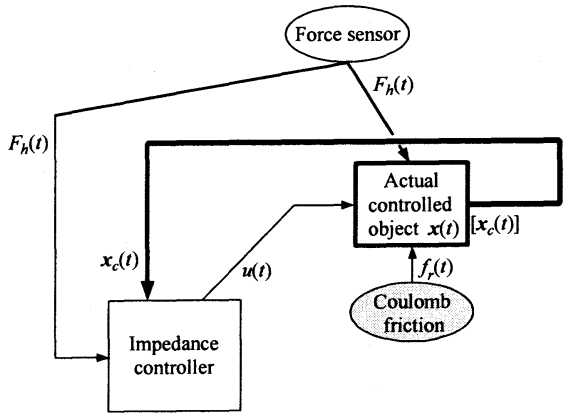

Fig. 7 Control system structure during the recovery action

フィードバック制御が動作する.フィードバック制御に は L Q I (Linear Quadratic Integral)サーボ制御器 ${ }^{(23),(24) ~}$ などを適用する. 本構造により, 扱いが面倒な固体摩擦 の影響をフィードバック制御により除去し, 線形システ ムと同様の応答を得ることができる.その上でインピー ダンス制御を適用することになるので, 設計者にとって 理解しやすい.

ただし，従来の制御系には大きな問題点が残されて いた. 1 章で述べたように,このようなシステムでは異 常発生をすみやかに検出できなければならない. しかし ながら, 従来の制御系では衝突等により発生する力が摩 擦力などの外乱と区別できないため,オンラインシミュ レータの目標軌道が衝突時と同じ方向の運動を続け, 制 御入力を与え続けることになる. すなわち, 従来の制御 系のままでは異常発生時に事態をさらに悪化させること になる.そこで, 本研究では従来著者が提案した各手法 の有用性を維持したまま, 異常検出機能を加える方法を 次節で提案する.

3.2 異常検出と対処の方法 異常検出には, モー 夕電流の動特性を活用して推定した電流を用いる.従来

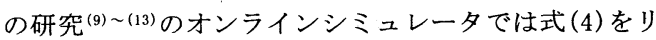


アルタイムで計算していた.この代わりに本研究では, 電流の動特性まで含めた式(1)をシミュレータの式とす る. シミュレータの状態量を $\boldsymbol{x}_{o l s}(t)=\left[\begin{array}{lll}\theta_{\text {mols }}(t) & \dot{\theta}_{\text {mols }}(t) & i_{o l s}(t)\end{array}\right]^{\mathrm{T}}$ とすると, 次式を計算 することになる.

$$
\dot{x}_{o l s}(t)=A x_{o l s}(t)+b u(t)+h F_{h}(t) \quad \cdots \cdot(12)
$$

そして,インピーダンス制御入力は次のようになる.

$$
u(t)=\left(K_{E}-\frac{r R}{\alpha K_{T}} \frac{I_{l}}{I_{l d}} D_{d}\right) \dot{\theta}_{\text {mols }}(t)-\frac{r R}{\alpha K_{T}}\left(1-\frac{I_{l}}{I_{l d}}\right) F_{h}(t)
$$

式(13)の導出には, 電流の動特性を省いた式(3)を用い たが, 電流を推定する目的では式 (1) を活用するのが本 研究の特徵である.ただし, サーボ制御の目標軌道とし てはシミュレータが生成する角変位 $\theta_{\text {mols }}(t)$ と角速度 $\dot{\theta}_{\text {mols }}(t)$ を用い, 電流 $i_{o l s}(t)$ は使わない.

モータの実際の電流も常に計測しておく，ある方向 に運動中, $i_{o l s}(t)$ と実際の電流 $i(t)$ の差 $e_{i}(t)$ の絶対值が あるしきい值 $e_{i t}>0$ を超えたら異常が発生したものと判 断する. そして, その方向一の制御入力を 0 とし, 運動 を停止させる. 異常検出直後も作業者の意図を反映し た対処が可能であるように, 反対方向への運動にはパ ワーアシスト制御を可能としておく.ただし, 異常発生 直後はシミュレータ中の角速度 $\dot{\theta}_{m_{0 l s}}(t)$ を用いずに, 実 際の角速度 $\dot{\theta}_{m}(t)$ を用いる式 (9)によりインピーダンス 制御入力をモータに与える. 異常発生直後は状況や発生 原因のわからないことが予想される. そこで, 前節で説 明したような異常発生による力と摩擦力などの外乱が区 別できない図 6 の構成は避ける.すなわち, 外乱に対す るロバスト性確保よりも実際の信号に基づいた着実な制 御を優先する.この状態の制御系を図 7 に示す.一定距 離以上, 反対方向に移動したところで式 (12)，(13）を用 いる通常の制御状態に戻す。この時までに, $x_{o l s}(t)$ 中の 各值を実際の值に合わせておく. 以上が, 本研究で提案 する異常検出と対処の方法である. なお, しきい值 $e_{i t}$ の 決定は, 個々の対象や環境, 問題設定に応じてチューニ ングする必要があり，本研究では文献 (14) などと同様 に，実験を繰り返すことで決定している.

\section{4. 実験による検討}

$4 \cdot 1$ 実験内容 本研究で提案する手法の有用性を 明らかにする目的で, 2 章で説明したシステムを対象と した実験による検討を行う.可動領域の片方の端から約 $20 \mathrm{~cm}$ の位置を位置 0 とし，ここを基点に端に向かって 作業者がパワーアシストを得ながら移動させる.この移 動を「行き」の移動と呼ぶことにする。この時, 作業者 は真下を向き, 可動領域端を見ない. 端に接触した感触 を得たら, 元の位置に戻してもらうように指示した.こ

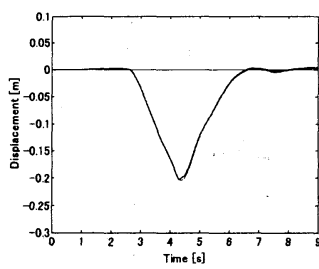

(a) Displacement of the table (thin line: reference)

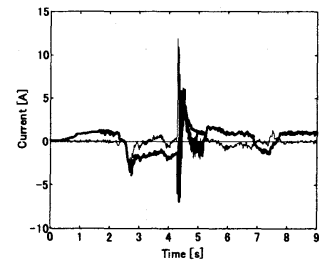

(c) Current of the motor (thin line: estimated)

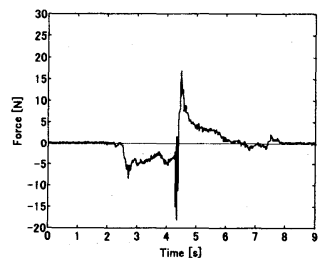

(e) Force of the operator

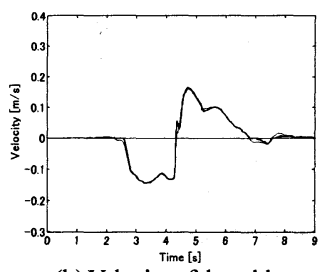

(b) Velocity of the table (thinline:reference)

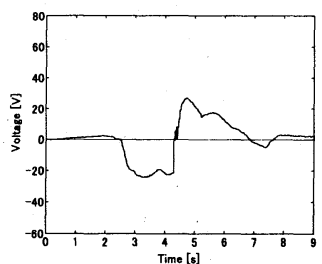

(d) Control input voltage

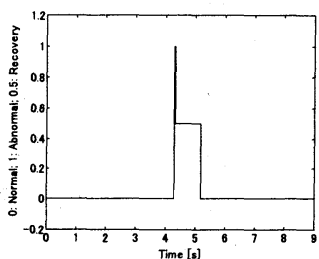

(f) Control modes
Fig. 8 Experimental results (Operator A/Proposed method)

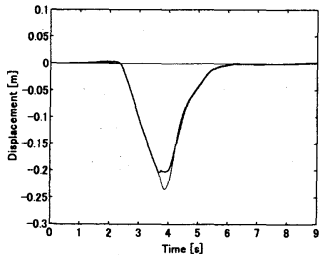

(a) Displacement of the table (thin line:reference)

(c) Current of the motor (thin line: estimated)

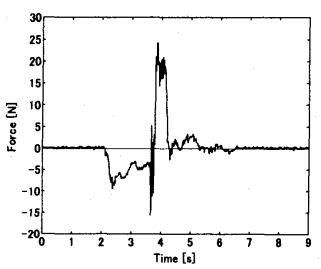

(e) Force of the operator

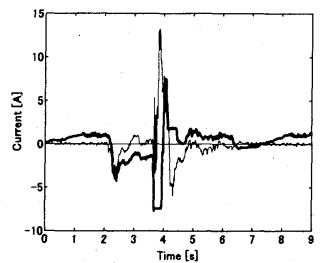

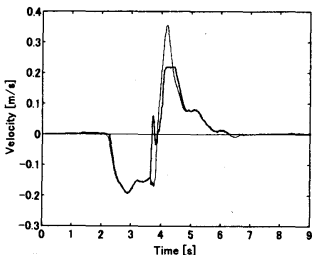

(b) Velocity of the table (thinline: reference)

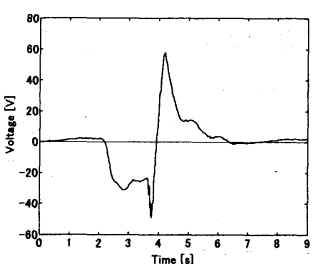

(d) Control input voltage

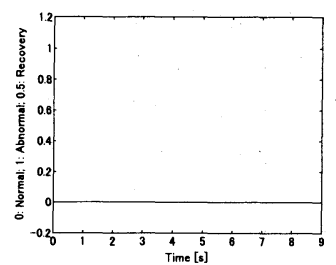

(f) Control modes
Fig. 9 Experimental results(Operator A/Conventional method) 


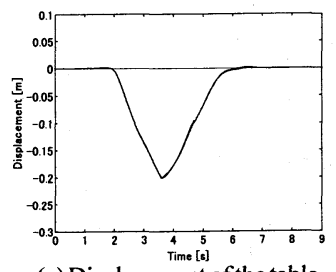

(a) Displacement of the table (thin line:reference)

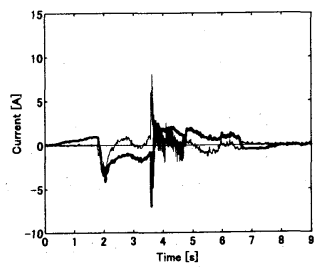

(c) Current of the motor (thinline: estimated)

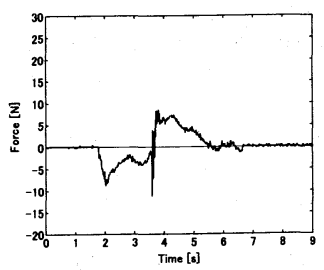

(e) Force of the operator

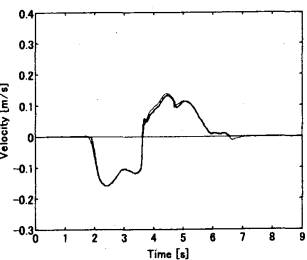

(b) Velocity of the table (thinline:reference)

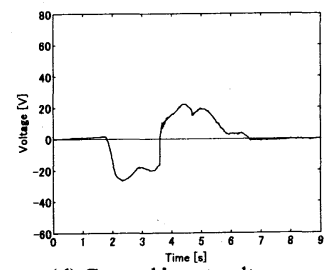

(d) Control input voltage

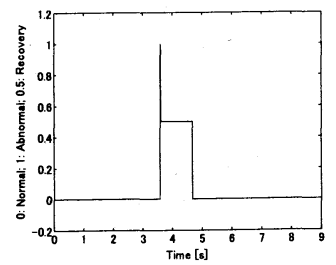

(f) Control modes

Fig. 10 Experimental results (Operator B / Proposed method)

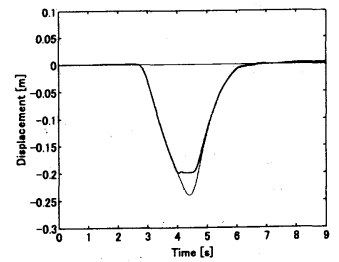

(a) Displacement of the table (thinline:reference)

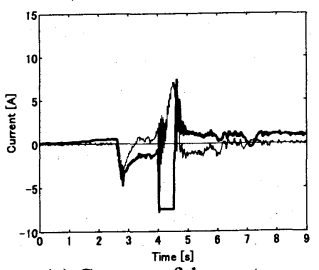

(c) Current of the motor (thin line: estimated)

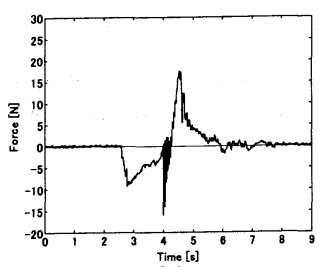

(e) Force of the operator

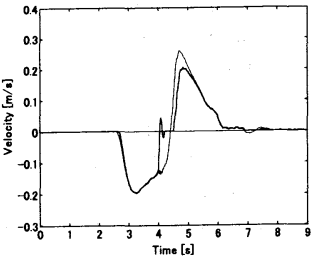

(b) Velocity of the table (thinline:reference)

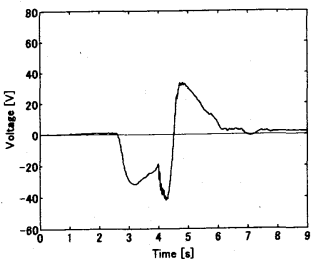

(d) Control input voltage

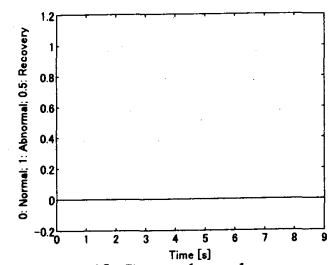

(f) Control modes

Fig. 11 Experimental results(Operator B/Conventional method)

の移動を「帰り」の移動と呼ぶ. 30 歳代の男性作業者 2 名（作業者 AおよびBとする.) を対象に実験を行っ た.

L Q I 制御は著者の従来の研究 ${ }^{(9)}$ (12) と同様のものを 用いる. モ一夕回転角変位の偏差 $\theta_{m}(t)-\theta_{\text {mols }}(t)$ を目標 值0に追従させるサーボ制御系とし, 評価関数中の重み には $\boldsymbol{Q}_{L Q I}=\operatorname{diag}\left[\begin{array}{lll}1.0 & 0 & 1.0\end{array}\right]$ を採用した. インピーダ ンス制御は $m_{d}^{\prime}=10.0 \mathrm{~kg}, c_{d}=30.0 \mathrm{~N} \cdot \mathrm{s} / \mathrm{m}$ として実現した. $e_{i t}=2.5 \mathrm{~A}$ とし, 衝突検出位置より $0.1 \mathrm{~m}$ 以上帰りの移動 が進んだところで元の制御状態に戻る設定とした. 実験 は各作業者とも異常検出を含む本研究の提案手法と, 含 まない従来手法の 2 種類について行った. 両手法とも数 回実施し, 得られた中の代表的な応答を図 8〜 11 に示 寸. 順に, 作業者 $\mathrm{A}$ の提案手法, 従来手法, 作業者 Bの 提案手法, 従来手法, の結果である. 各図内では, (a) テーブル変位, (b)テーブル速度, (c) モータ電流, (d) 制 御入力電圧, (e) 作業者操作力, (f) 制御モードを示して いる. (a) と (b)では, オンラインシミュレータが生成す る目標軌道を細線で示している. (c) ではシミュレータ が推定している電流を細線で示している.テーブル静止 時に見られる電流の発生は力覚センサのオフセット誤差 の影響である. なお, 提案手法では異常検出時と通常の 制御状態に戻る時の 2 度,シミュレータの状態量を実際 の状態量に一致させている.ただし, (c) 細線の表示で は一致する様子を反映させていない. (f)では, 值0が通 常の制御状態, 1.0 が異常検出, 0.5 が異常検出時と反対 の方向のみ移動可の状態を意味している.

$4 \cdot 2$ 考察各作業者が各手法に対して行った数回 の実験結果はどれも類似したものであった. 駆動系の固 体摩擦の影響やモータパラメータの不確かさなどから, モ一夕電流の推定值は実際の值とある程度異なっている が, 提案手法の異常検出は問題なく行われた. 作業者の 違いにかかわらず, 従来手法と比較して, 提案手法では 接触の感触を得た直後, すぐに帰りの動作が始まってい る. また, 帰りの動作を始める際の作業者操作力は小さ い.ゆえに, 作業者が何らかの異常な感触を得たとして も, 直後から作業者の意図に従った反対方向の運動が小 さな作業力で実現されていることが理解できる．さら に, 通常の制御状態に戻る瞬間も作業者操作力は連続的 に変化しており,この際の作業者への影響はほとんど見 られない.

一方, 従来手法では, 接触後, 反対方向に相当大きな 力を入れて初めて帰りの動作が可能になっている.こ れは, 接触後も行きの方向に進み続けるオンラインシ ミュレータ中の状態量にモータが追従するため, この 状態量を反対方向の運動に変えるまでの大きな作業力 
をハンドルに与えなければならないことによる.実際に は両作業者とも従来手法の場合に,テーブルが端にくっ つき, 少しの間自由に動かせない印象を受けた.これは 安全性の観点から問題となる現象である。結果からは モータ電流が使用しているパワーアンプの制限值にまで 至って飽和している様子が見られる. 以上の比較から， 本研究で提案した手法の有用性が理解できる.

\section{5.おわりに}

最近, 各種生産現場での利用が活発に検討されている パワーアシスト機器の制御に関して, 本研究ではソフト ウェア的に異常検出可能な制御系設計法の一つを提案し た. 具体的には, 従来の研究同様, DCサーボモータの 使用を前提とし, モータ電流の動特性を導入して推定し た電流と実際の電流との差から異常状態を検出する手法 である. 本手法は, 従来著者が提案したパワーアシスト に関する各手法 ${ }^{(9)}$ ( (13) に対して, それらの有用性を維持 したまま,ソフトウェア上の小さな変更のみで付加でき る.ゆえに,より安全性を向上した上で従来手法を実装 することが可能となった. 実験により本手法の有用性を 明らかにした。

本研究の内容の一部は文部科学省科学研究費補助金 (若手研究 (B) 課題番号：16760184）を受けて実施され ており，謝意を表する。

\section{文献}

(1) Yamada, Y. et al., Proposal of Skill-Assist for Mounting Operations in Automobile Assembly Processes, Transactions of the Japan Society of Mechanical Engineers, Series C, Vol.68, No.666(2002), pp.509-516.

(2) Konosu, H. et al., Practical Development of Skill-Assist, Journal of the Robotics Society of Japan, Vol.22, No.4 (2004), pp.508-514

(3) Hogan, N., Impedance Control: An Approach to Manipulation: Parts I-III, Transactions of the ASME, Journal of Dynamic Systems, Measurement, and Control, Vol.107, No.1 (1985), pp.1-24.

(4) Hayashi, R. et al., Positioning Operation of an Object Using a Power Assist Device, Proceedings of 51 st Conference of Tokai Branch of Japan Society of Mechanical Engineers, No.023-1 (2002-3), pp. 127. 128.

(5) Kondo, K. et al., Autonomous Production System Realizing Collaboration of Operators and Machines -Its Application to Shaft Inserting System for Moving Object-, Proceedings of 2004 JSME Conference on Robotics and Mechatronics, No.04-4 (2004-6), 2P1$\mathrm{H}-14$

(6) Miyoshi, T. et al., Construction of Power Assist System for Overhead Crane, Transactions of the Japan Society of Mechanical Engineers, Series C, Vol.70, No.696(2004), pp.2427-2434.

(7) Hara, S., Positioning of a Cart by Means of a Smooth Switching from Servo Access Control to Impedance Control, Transactions of the Japan Society of Mechanical Engineers, Series C, Vol.70, No.689 (2004), pp.127-134.

(8) Hara, S., A Smooth Switching from Power-Assist Control to Automatic Transfer Control and Its Application to a Transfer Machine, to appear in IEEE Transactions on Industrial Electronics.

(9) Hara, S., Mode Switching Control Method for Man-Machine Collaborated Robotic Systems (Switching from Power-Assist Mode to Automatic Positioning Mode), Transactions of the Japan Society of Mechanical Engineers, Series C, Vol.71, No.706 (2005), pp.1907-1913.

(10) Hara, S., Mode Switching Control Methods for Man-Machine Collaborated Robotic Systems, Proceedings of 2005 IEEE International Conference on Mechatronics and Automation, (20057), pp.321-328.

(11) Hara, S., Positioning Control Method by Means of a Switching from Automatic Traveling Mode to Semi-Automatic Settling Mode (Proposal of Semi-Automatic Settling Mode), Transactions of the Japan Society of Mechanical Engineers, Series C, Vol.71, No.708 (2005), pp.25492556.

(12) Hara, S., Positioning Control of Man-Machine Systems by Means of Semi-Automatic Settling Mode, Proceedings of the Third International Conference on Computational Intelligence, Robotics and Autonomous Systems, (2005-12), IC1-1

(13) Hara, S., Controller Design Method for Robustness Improvement of Power-Assist Control, Transactions of the Japan Society of Mechanical Engineers, Series C, Vol.70, No.690(2004), pp.419-426.

(14) Kato, H. et al., Impedance Control for a Power Assist Device Considering Stability of Contact Tasks, Proceedings of 2004 JSME Conference on Robotics and Mechatronics, No.04-4 (2004-6), 1P1H-36.

(15) Lumelsky, V. J. and Cheung, E., Real-Time Collision Avoidance in Teleoperated Whole-Sensitive Robotarm Manipulator, IEEE Transactions on Systems, Man, and Cybernetics, Vol.23, No.1 (1993), pp.194-203.

(16) Takakura, S. et al., An Approach to Collision Detection and Recovery Motion in Industrial Robot, Proceedings of the 15th Annual Conference of the IEEE Industrial Electronics Society, Vol.2 (198911),pp.421-426.

(17) Yamada, Y. et al., A Robot System with Safe Contact Detection and Stopping Capabilities Based on Human Pain Tolerance, Transactions of the Japan Society of Mechanical Engineers, Series C, Vol.63, No.614 (1997),pp.3552-3557.

(18) Kosuge, K. et al., Collision Detection System for Manipulator Based on Adaptive Control Scheme, Transactions of the Society of Instrument and Control Engineers, Vol.39, No.6(2003), pp.552-558.

(19) Hara, S. and Yoshida, K., Simultaneous Optimization of Positioning and Vibration Control Using Time-Varying Criterion Function, Transactions of the Japan Society of Mechanical Engineers, Series C, Vol.60, No.570(1994), pp.424-429.

(20) Hara, S. et al., Simulation-Based Reference Design and Its Application to Positioning Control of Vibration Systems, Transactions of the Japan Society of Mechanical Engineers, Series C, Vol.68, No.672 (2002), pp.2241-2248.

(21) Hara, S., Reference Trajectory Generation Method for Servo Positioning Control of Flexible Structures, Transactions of the Japan Society of Mechanical Engineers, Series C, Vol.66, No.649(2000), pp. 3085-3092.

(22) Hirata, M. et al., Head Positioning Control of a Hard Disk Drive Using $H^{\infty}$ Control Theory, Transactions of the Society of Instrument and Control Engineers, Vol.29, No.1 (1993), pp.71-77.

(23) Nonami, K. et al., Control Systems Design by MATLAB (in Japanese), (1998), pp.96-99, Tokyo Denki University Press

(24) Hara, S., Unified Design of Time-Varying Gain Type Access Control and Integral Type Servo Control by Means of Nonstationary Optimal Control Method, Microsystem Technologies, Vol.11, No.8-10 (2005), pp.676-687. 